\title{
Sosyal Medya Uygulamalarının Öğrencilerin Akademik ve İletişim Becerilerine Etkisinin Değerlendirilmesi: Mesleki ve Teknik Anadolu Lisesi Örneği
}

\author{
Mehmet FIDAN¹ ve Metin KUZHAN² \\ Öz
}

Teknoloji temelli araçların ve uygulamaların iletişim ve bilgiye erişim alanlarında avantajlarının olması bu araçların kullanımının yaygın olmasına katkı sağlamaktadır. Bu aşamada sıralanan araçların bireylerin ve özellikle öğrencilerin iletişim ve akademik becerileri üzerindeki etkilerinin gözlemlenmesi gerekmektedir. Çünkü bu becerilerinin gelişimi akademik niteliklerin yanında bireysel ve toplumsal iletişim açısından da önemlidir. Özellikle sosyal medya uygulamalarının iletişimsel ve akademik yönden değerlendirilmesinin eğitim süreçlerine olumlu etkisinin olacağ1 düşünülmektedir. Sosyal medya uygulamalarının öğrencilerin akademik ve iletişim becerilerine etkisinin değerlendirilmesinin amaçlandığı bu araştırmada tarama modelinden yararlanılmıştır. Araştırma sürecinde verilerin elde edilmesinde sosyal medya uygulamalarının öğrencilerin akademik ve iletişim becerilerine etkisi anketi kullanılmıştır. Araştırmada amaçsal örnekleme yönteminden yararlanılmıştır. Araştırmanın örneklemi mesleki ve teknik Anadolu Lisesi öğrencilerinden oluşmaktadır. Araştırmaya toplamda 92 öğrenci katılmıştır. Araştırmaya katılan öğrencilerin eğitim gördükleri alanlar bilişim, elektrik elektronik ve inşaat teknolojileri bölümleridir. Çalışmada nicel araştırma yöntemleri kullanılmıştır. Öğrencilerin ankette yer alan maddelere verdikleri cevaplar t testi, ANOVA, frekans (f) ve yüzdelik (\%) dilimler açısından analiz edilmiştir. Araştırmaya katılan öğrencilerin çoğunluğunun, sosyal medya uygulamalarını kullandıklarını belirtikleri; bu uygulamaların ancak eğitsel amaçlar doğrultusunda kullanıldığında olumlu etkilerinin olacağını düşündükleri; bu tür uygulamaları kullanmanın öğretmenleri tarafindan tanınırlığa olumlu etkilerinin bulunduğu konuları ön plana çıkan sonuçlar arasında yer almaktadır. Bu nedenle ilgili uygulamaların eğitsel açıdan değerlendirilmesi önemli görülmektedir.

Anabtar Kelimeler: Akademik beceriler, İletişim becerileri, Sosyal medya uygulamaları

\section{Evaluation of the Effects of Social Media Applications on Students' Academic and Communication Skills: The Case of Vocational and Technical Anatolian High School}

\begin{abstract}
The advantages of technology-based tools and applications in the areas of communication and access to information make the use of these tools widespread. At this stage, the effects of the listed tools on the communication and academic skills of individuals and especially students should be observed. As the development of these skills is important in terms of individual and social communication as well as academic qualifications. It is thought that the communicative and academic evaluation of social media applications will have a positive effect on educational processes. In this study, as aims to evaluate the effects of social media applications on students' academic and communication skills, the scanning model was used. During the research process, the survey of the effect of social media applications on students' academic and communication skills was used to obtain the data. The purposive sampling method was used in the research. The sampling group of the research consists of vocational and technical Anatolian High School students. A total of 92 students participated in the research. The fields of education of the students participating in the research are the departments of informatics, electrical electronics, and construction technologies. Quantitative research methods were used in the study. The answers given by the students to the items in the survey were analyzed in terms of $t$-test, ANOVA, frequency (f), and percentage (\%) rates. Some of the prominent results of the research can be listed as follows: Most of the students participating in the study stated that they use social media applications. It was determined that most of the students participating in the study think that these applications will have positive effects only when used for educational purposes. The majority of the students participating in the study stated that using such practices had positive effects on recognition by their teachers. For this reason, it is important to evaluate the relevant applications from an educational point of view.
\end{abstract}

Key Words: Academic skills, Communication skills, Social media applications

\section{Atıf İçin / Please Cite As:}

Fidan, M. ve Kuzhan, M. (2022). Sosyal medya uygulamalarının öğrencilerin akademik ve iletişim becerilerine etkisinin değerlendirilmesi: Mesleki ve teknik Anadolu lisesi örneği. Manas Sosyal Araştırmalar Dergisi, 11(1), 81-97.

Geliş Tarihi / Received Date: 17.05.2021

Kabul Tarihi / Accepted Date: 3.09.2021

\footnotetext{
${ }^{1}$ Doç. Dr. - Aksaray Üniversitesi, Eğitim Fakültesi, Türkçe ve Sosyal Bilimler Eğitimi Bölümü, fidanm3838@gmail.com D ORCID: 0000-0002-9347-2992

2 Öğretmen - Bahçelievler Türk Telekom MTAL, İstanbul, metinkuzhan@hotmail.com

(D) ORCID: 0000-0001-6420-8327
} 


\section{Giriş}

Teknolojik gelişmeler toplumsal yaşamın genelinde olduğu gibi eğitim alanında da etkisini göstermektedir. Bu konuda Güneş (2012, s. 1; 2011, s. 124) teknolojik gelişmelerin eğitim kurumlarını da etkilediğini belirterek nitelikli birey yetiştirmeye dikkat çeker ve bu yöndeki gelişmelere uyum sağlamada dili önemli konumda görür. Bu durum eğitim süreçlerinde öğrencilere verilecek olan dil eğitimlerinin önemini ortaya koymaktadır.

Öğrencilerin dil becerilerinin gelişimi akademik niteliklerin yanında bireysel ve toplumsal iletişim açısından da önemlidir. Bu konuda Temizyürek (2007, s. 129) konuşmanın çok boyutluluğuna dikkat çeker ve onun önemli bir toplumsal iletişim arac1 olduğunu vurgular. Derwing ve Waugh (2012, s. 1) göçmenlerin resmi dil becerilerini kullanmalarına yönelik araştırmalarında, bireylerin dili kullanabilme becerisinin içerisinde yaşanılan toplumla uyum sağlamada önemli etkisinin olduğunu belirtirler. Bu durum toplumsal uyum açısından dil becerilerinin önemli özelliklerindendir. Bu yüzden öğrencilerin toplumsal uyum sağlamalarında dil becerilerinin gelişimsel özelliklerinin göz önünde bulundurulması önemlidir.

Bireysel ve toplumsal iletişimin kurulmasında dil becerilerinin kullanım biçimi önemli konumda bulunur. Sosyal uyumla birlikte, girişimcilik, etkili hitabet gibi beceriler bireylerin dil becerilerinin dişa yansımaları olarak nitelendirilebilir. Bu önemli durum, araştırmacıların özellikle dil becerilerinin geliştirilmesi konusuna odaklanmalarına neden olmuştur. Bu alanla ilgili yapılan araştırmaların genelinin ögrencilerin dil becerileri konusunda yaşadıkları sorunların en aza indirgenebilmesi konusunda olduğu görülmektedir (Fidan, 2019; Güneş, 2013; Karatay, 2007; Temizyürek, 2007). Sosyal medya uygulamalarının kitle iletişim, bilgi paylaşımı gibi yönlerinin bulunması, bu uygulamaların öğrencilerin iletişim ve akademik becerilerinin gelişimine nasıl etkide bulunduğu konusunu gündeme getirmektedir.

İletişim becerilerini etkili biçimde kullanabilme yeteneği çok boyutlu bir yapıda bulunmaktadır. Bu durum belirtilen ögelerin birbirini etkilemesi şeklinde gelişim göstermektedir. Sigman ve McGovern (2005, s. 22) araştırmalarında otizmli çocukların dil becerilerinin gelişimlerini inceler ve onlara göre öğrencilerin dil becerilerinin gelişimleri hakkında görüşte bulunabilmek için, öğrencilerin ev, okul gibi çevrelerdeki davranışları hakkında düzenli bilgiye sahip olunması gerekmektedir. Ayrıca araştırmacılar otizmli çocukların dil becerilerinin gelişiminde hassas dönemler bulunduğunu belirterek çocukların dilsel becerilerinin gelişiminde erken müdahaleye dikkat çekmektedirler (Sigman, McGovern, 2005, s. 22). Bu etkenlere bir başka örnek olarak Eriksson'un vd. (2012, s. 338) araştırma sonuçları gösterilebilir. Eriksson vd. (2012, s. 338) araştırmasında bebeklik döneminde kızların erkeklere göre iletişimsel jestler ve ilk kelime kullanımı yönünden daha önde olduklarını belirtmektedirler. Bir diğer araştırmada Puolakanaho vd. (2007, s. 923) çocukların "fonolojik farkındalık, kısa süreli bellek, hızlı adlandırma, anlamlı sözcük dağarcığı, sözde tekrarlama ve harf adlandırma" gibi çeşitli ögelerle okuma engelleri konusundaki risklerin tahmin edilebileceğini belirtmektedirler. Nation, Cocksey, Taylor ve Bishop (2010, s. 1038) ise araştırmalarında sözlü ve yazılı dil becerileri arasındaki etkileşime dikkat çekerler. Nation, Cocksey, Taylor ve Bishop (2010, s. 1038) erken çocukluk döneminde görülen bazı dilsel eksikliklerin daha sonra çocukların okuduklarını doğru anlamalarına olumsuz etkide bulanabileceğini belirtirler. Nation ve Snowling (2004, s. 352) dil becerileri ile okuma gelişimi ilişkisini inceledikleri araştırmalarında sözel dil becerilerinin bireylerin kelimeleri tanımalarında etkili olduğunu belirtmektedirler. Bu durum okuma ve sözel dil becerileri arasındaki etkileşimi göstermesi açısından önemlidir. Geers, Nicholas ve Sedey (2003, s. 57) de işitme sorunu yaşayan çocuklara yönelik araştırmalarında öğrencilerin eğitsel ortamlarda dil becerilerinin gelişiminin belirlenmesinde "konuşma ve işitsel becerilerin geliştirilmesini” vurgulamaktadır.

Bireylerin dil gelişimi onların iletişim becerileri ile bağlantılıdır. Bu konuda özellikle öğretmenler hitap ettikleri kitle ve görev sorumlulukları açısından önemli konumda bulunurlar. Jones, Bouffard ve Weissbourd (2013, s. 62-65) bu konudaki araştırmalarında sosyal ve duygusal gelişimin öğretmenleri, öğrenci ile iletişim kurma, etkili öğretim yapabilme gibi birçok konuda etkilediğini belirtmektedirler. Benzer bir çalışmada Nelson, Welsh, Trup ve Greenberg (2011, s. 187-188) çocuklarda dil gecikmesinin (language delay) onların akademik, iletişimsel becerilerini etkileyebileceğini belirtmektedir.

Dil ve iletişim becerilerinin gelişimine teknoloji ile birlikte yaygınlık kazanan araçların etkisinin olduğu araştırmalarla ortaya konmuştur. De Jonge ve Kemp (2012, s. 65) araştırmalarında çok sık mesajlaşmanın dilsel gelişime etki edebileceğini belirtir ve bu durumun dilsel gelişim yönünden zayıf olan öğrencilerin yazılı ifade becerilerinin olumsuz etkilenmesine neden olabileceğini ifade eder. Bireylerin hayatına birçok yönden etkide bulunan teknoloji, eğitimi de etkilemektedir. Bu durum dil becerilerinin geliştirilmesine yönelik etkinliklerde de teknoloji ile uyum sağlanmasını zorunlu kılmaktadır. Çakır’n (2010) araştırması 
incelendiğinde bireylerin dil becerilerinin gelişiminde teknolojiden nasıl faydalanılabileceğine değinildiği görülmektedir. Bu konuda Çakır (2010, s. 173) bireylerin yabancı dil becerilerinin gelişiminde internet temelli bir iletişim yöntemi olan elektronik posta kullanımının etkili olacağı görüşündedir.

İnternet kullanımının yaygınlık kazanması internet tabanlı sosyal medya uygulamalarının da bu yönde gelişmesini sağlamıştır. Özellikle internetin kullanım ve erişim yönünden geniş kitlelere ulaşması bireylere bilgiye erişim yönünden çeşitli avantajlar sağlamıştır. $\mathrm{Bu}$ duruma öğretim programlarında da değinilmektedir. Örneğin, Türkçe Dersi Öğretim Programı'nda sosyal medya uygulamalarının bu özelliğinin göz önünde bulundurulduğu görülmektedir (MEB, 2019, s. 42-50). Programda öğrencilerin yazdıkları metinleri sosyal medya aracılığı ile paylaşmaya teşvik edilmeleri de yer almaktadır (MEB, 2019). Bu durum sosyal medya uygulamalarına eğitsel nitelik kazandırılması açısından önemlidir.

Sosyal medya uygulamaları ve öğrenci etkileşimi konulu bazı araştırma sonuçları şu şekilde siralanabilir:

Ayaydın ve Yıldız Ayaydın (2018, s. 78) sosyal medya uygulamalarının öğrencilerin değerlerinin gelişimi yönünden olumlu ve olumsuz etkilerinin bulunduğunu tespit etmişlerdir. Demir (2016, s. 44-45) araştırmasında sosyal medya uygulamalarının yoğun kullanımının öğrencilerin iletişim tercihlerini etkileyebildiği sonucuna ulaşmıştır. Öğrencilerin sosyal medya kullanım tarzlarını ve sosyal medya bağımlılıklarını inceleyen çeşitli araştırmalar bulunmakta, özellikle bu araştırmalarda öğrencilerin sosyal medya kullanımlarının cinsiyet değişkeni yönünden farklılaşabildiği görülmektedir (Deniz ve Gürültü, 2018, s. 365; Baştürk Akca, Sayımer ve Ergül, 2015, s. 83). Öğrencilerin sosyal medya bağımlığının cinsiyet değişkeni açısından farklılaşmadığına yönelik araştırma sonuçları da bulunmaktadır (Baz, 2018, s. 289). Araştırma sonuçlarında bu durumun oluşmasında incelenen örneklemlerin okul/sınıf düzeylerinin farklı olmasının etkili olabileceği düşünülmektedir. Yaylak ve İnan (2018, s. 24) ise sosyal bilgiler öğretmenlerine yönelik araştırmalarında öğretmenlerin sosyal medya uygulamalarının eğitsel amaçlar doğrultusunda kullanıldığında olumlu etkilerinin olacağını ifade ettiklerini belirtmektedir. Tutgun Ünal (2015, s. 182) üniversite öğrencilerinin sosyal medya kullanımlarına yönelik araştırmasında, öğrenciler arasında sosyal medya bağımlilığının yüksek oranda olduğunu tespit eder. Ayrıca sosyal medya bağımlılığının bireyler arasında çeşitli iletişim sorunlarına da sebep olduğunu ifade eder (Tutgun Ünal, 2015, s. 184). Bu doğrultuda araştırmamızda sosyal medya uygulamalarının öğrencilerin akademik ve iletişim becerilerine etkisinin öğrencilerin görüşleri doğrultusunda değerlendirilmesi amaçlanmıştır. Öğrencilerin bu yöndeki görüşlerinin alınmasının araştırmada incelenen verilere ulaşılmasına olumlu yönde katkı sunacağı düşünülmektedir.

Bu çalışmanın temel araştırma sorularını şu şekilde sıralamak mümkündür:

1. Sosyal medya uygulamaları mesleki ve teknik Anadolu Lisesi öğrencilerinin görüşlerine göre öğrencilerin akademik becerilerini etkiliyor mu?

2. Sosyal medya uygulamaları mesleki ve teknik Anadolu Lisesi öğrencilerinin görüşlerine göre ögrencilerin iletişim becerilerini etkiliyor mu?

3. Sosyal medya uygulamaları mesleki ve teknik Anadolu Lisesi öğrencilerinin görüşlerine göre akademik ve iletişim becerilerini (eğer etkiliyorsa) hangi açllardan etkilemektedir?

\section{Yöntem}

Sosyal medya uygulamalarının öğrencilerin akademik ve iletişim becerilerine etkisinin öğrencilerin görüşleri vasıtasıyla tespit edilmesinin amaçlandığı bu araştırmada tarama modelinden yararlanılmıştır. "Bir grubun belirli özelliklerini belirlemek için verilerin toplanmasını amaçlayan çalışmalar" (Büyüköztürk, Kılıç Çakmak, Akgün, Karadeniz ve Demirel, 2019, s. 15) şeklinde tanımlanan tarama modelinin Karasar (2009, s. 77) durum betimlenmesinde kullanıldığını belirtir. Araştırmanın bu bölümünde evren-örneklem, veri toplama araçları, geçerlilik ve güvenilirlik çalışmaları, verilerin analizi başılkları yer almaktadır.

\section{Evren - Örneklem}

$\mathrm{Bu}$ araştırmanın evreni İstanbul ilinde bulunan bir Mesleki ve Teknik Anadolu Lisesinin öğrencilerinden oluşmaktadır. Araştırmada amaçsal örnekleme yöntemi kullanılımıştır. "Amaçsal örnekleme çalışmanın amacına bağlı olarak bilgi açısından zengin durumların seçilerek derinlemesine araştırma yapılmasına olanak tanır." (Büyüköztürk, Kılıç Çakmak, Akgün, Karadeniz ve Demirel, 2019, s. 92). Araştırmanın örnekleminin Mesleki ve Teknik Anadolu Lisesi öğrencilerinin seçilmesinin sebebi bu ögrencilerin eğitimlerinin teknoloji alanlarında olmasıdır. Bu vasıta ile teknoloji alanında eğitim gören 
öğrencilerin yine bir teknolojik araç olan sosyal medya uygulamalarına yönelik tutumlarının tespit edilmesi amaçlanmışıır. Araştırmanın örneklemleri ilgili okulun öğrencileri arasından amaçsal örneklemi yöntemi ile seçilmiştir. Bu araştırma 2020-2021 Eğitim Öğretim yllında Mart 2021 - Nisan 2021 tarihleri aralı̆̆ında yapılmıştır. Araştırmaya yüz yüze eğitimin olduğu dönemlerde araştırma yapılan okula gelen öğrenciler katılmıştır. Araştırma sürecine katılımda gönüllülük ilkesi aranmıştır. Katılımcılara istedikleri anda araştırma sürecinden ayrllabilecekleri belirtilmiştir. Maddelerin yer aldığı ölçekler öğrencilere yazılı form şeklinde, sağlık koşulları açısından gerekli tedbirler alınarak uygulanmışır. Araştırmanın örneklemine ait bilgilerin yer aldığı grafik aşağıda yer almaktadır:

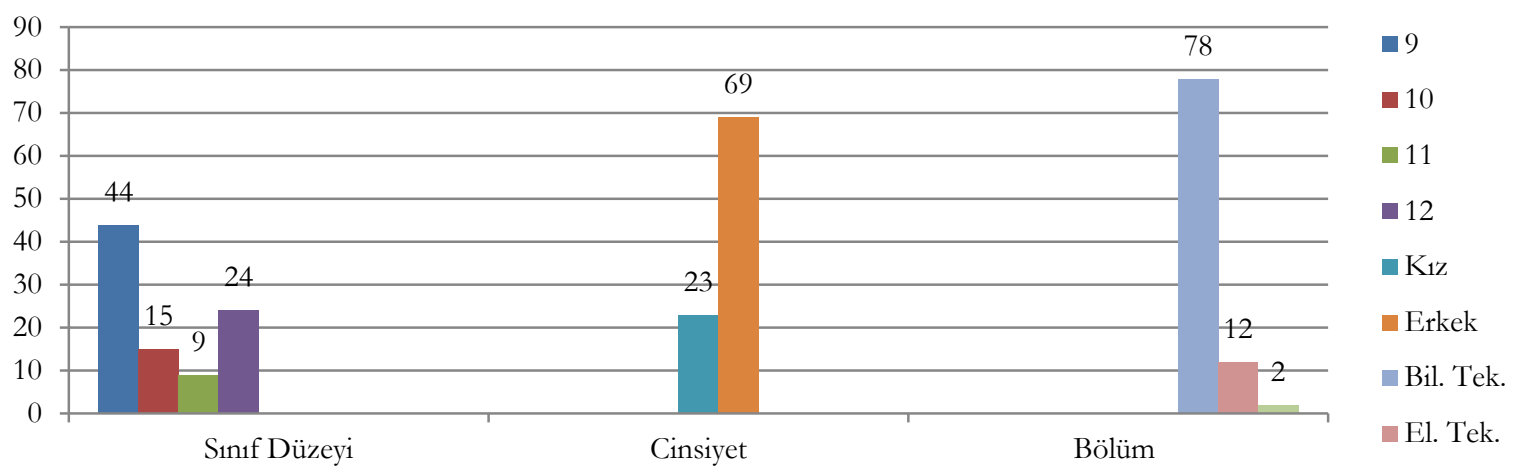

\section{Grafik 1. Araştırmanın örneklemi}

Araştırma yapılan dönemde okulda Anadolu Teknik Programı ve Anadolu Meslek Programlarında toplamda 750 öğrenci olduğu tespit edilmiştir. Araştırmaya bilişim, elektrik elektronik ve inşaat teknolojileri bölümlerinden toplamda 92 öğrenci katılmıştır. Sınıf düzeyleri açısından dokuzuncu sınıftan 44, onuncu sınıftan 15, on birinci sınıftan 9, on ikinci sınıftan 24 öğrenci araştırmaya katulmıştır. Araştırmaya 25 kız öğrenci, 69 erkek öğrenci katılmıştır. Araştırmaya bilişim teknolojileri alanından 78, elektrik elektronik teknolojileri alanından 12 ve inşaat teknolojileri alanından 2 öğrenci katılmıştır. Araştırma yapılan dönemde bazı sınıf düzeylerinde yüz yüze eğitim yapılırken bazı sınıf düzeylerinde uzaktan eğitim yapılmıştır. Araştırma okula devam eden öğrencilere gönüllülük ilkesine göre uygulandı̆̆1 için sınıf ve bölüm düzeyinde katılım sayılarında eşitlik durumu gözetilmemiştir. Okuldaki öğrencilerin ağırlıklı olarak erkeklerden oluşması durumu örneklemlerdeki bu yöndeki sayısal dağılımı da etkilemiştir.

Bu araştırma Aksaray Üniversitesi Rektörlüğü İnsan Araştırmaları Etik Kurulunun 2021/01-33 protokol numaralı başvuru ve 22.02.2021 tarihli toplantısında alınan etik ilkelere uygunluk kararı çerçevesinde yapılmıştır. Araştırma İstanbul İl Milli Eğitim Müdürlüğünün 05.08.2020 tarih ve 5909041120-E.10217208 sayılı izni ile uygulanmıstır.

\section{Veri Toplama Araçları}

$\mathrm{Bu}$ araştırmada verilerin toplanması sürecinde araştırmacılar tarafindan geliştirilen tutum ölçeği kullanılmıştır. Araştırmada kullanılan tutum ölçeğinde yer alan ifadelerin hazırlanması sürecinde öncelikli olarak araştırmanın kapsamı dikkate alınmıştır. Bu kapsamda ifadelerin oluşturulmasında sosyal medya uygulamalarının öğrencilerin iletişimsel ve akademik becerilerine etkilerine yönelik maddeler hazırlanmaya çalısıılmıştır. İfadelerin hazırlanmasında anlaşılırlık ve sadelik ön planda tutulmuştur. Ayrıca ifadelerin konu alanlarının belirlenmesinde Türkçe Öğretim Programında yer verilen amaçlar, değerler, yetkinlikler konuları göz önünde bulundurulmuştur (MEB, 2019). İfadelerin konu alanları şu şekildedir: gelişimsel özellikler, özgüven, değerler sistemi, akran-öğretmen-aile ile iletişim, uygulamaların akademik başarıya etkisi, uygulamaların anlama ve anlatma becerilerine etkisi, uygulamaların zihinsel becerilere etkisi, uygulamalarda güvenli bilgiye erişim ve bilgi paylaşımı, uygulamaların kullanımı yönünden rehberlik. $\mathrm{Bu}$ konu alanları araştırmacılar tarafından belirlenmiş olup araştırmacıların alanlarının anadili eğitimi ve bilişim teknolojileri alanlarında olması konuya disiplinler arası bakış açısıyla yaklaşılmasına imkân sağlamıştır. Hazırlanan ifadeler araştırmanın uygulanacağı okulda bulunan konu alanı ile ilgili beş öğretmene gönderilerek görüşleri alınmıştır. Öğretmenlerin önerileri doğrultusunda bazı maddelerde güncellemeler yapılmıştır.

Araştırma soruları doğrultusunda geliştirilen ölçekte yer alan maddelere öğrencilerin verdikleri cevaplar incelenmiştir. Akademik ve iletişim becerileri çok boyutlu bir yapıda bulunmaktadır. Bu durum akademik ve iletişim becerilerinin tespit edilmesinde kapsamlı ve güvenilir ölçme araçlarının geliştirilmesini 
gerekmektedir. Araştırmada kullanılan ölçme aracının geliştirilme süreci geçerlilik ve güvenilirlik başlı̆̆ında açıklanmıştır. Araştırma sürecinde veri toplamak için kullanılan tutum ölçeğinde bulunan ifadeler makalenin sonunda yer almaktadır.

\section{Geçerlilik ve Güvenilirlik Çalışmaları}

$\mathrm{Bu}$ araştırmada verilerin elde edilmesinde sosyal medya uygulamalarının öğrencilerin akademik ve iletişim becerilerine etkisi tutum ölçeği kullanılmıştır. Araştırmada verilerin elde edilmesi sürecinde kullanılan ölçekteki yer alan maddelere yönelik cevaplar beşli likert tipi tutum ölçeği şeklinde tasarlanmıştır. $\mathrm{Bu}$ doğrultuda maddelere yönelik cevaplar "Kesinlikle Katılıyorum, Katıllyorum, Kararsızım, Katılmıyorum, Kesinlikle Katılmıorum"dur. Öğrencilerin verdikleri cevaplardan elde edilen bilgiler Spss 20 programı vasıtası ile istatistiksel veriye dönüştürülmüştür. $\mathrm{Bu}$ aşamada ölçekteki maddelere yönelik cevaplar analiz programına "Kesinlikle Kat1liyorum: 5, Kat1liyorum: 4, Kararsızım: 3, Katılmiyorum: 2 Kesinlikle Katılmıyorum: 1" şeklinde kodlanmıştır. Puanlamaya ait bu bilgilere yer verilmesinin sebebi analiz aşamasında puan yönünden yorumlamalarda açılılı sağlanabilmesidir.

Araştırma sürecinde sosyal medya uygulamalarının öğrencilerin akademik ve iletişim becerilerine etkisinin belirlenebilmesi amacıyla hazırlanan beşli likert tipi tutum ölçeğinin kapsam geçerliğinin sağlanabilmesi için uzman görüşüne başvurulmuştur. Kapsam geçerliliği yönünden maddeleri değerlendiren 3 alan uzmanı (doktora derecesine sahip öğretmen) ölçeğin bu yönden uygun olduğunu belirtmiştir.

Araştırma sürecinde kullanılan bu ölçeğin geçerlilik ve güvenilirlik yönlerinin tespit edilebilmesi için çeşitli istatistiksel hesaplamalar yapılmışır. İlk olarak alınan izinlere ve gönüllü katılım esasına göre 50 öğrenciye ön test yapılmıştır. Ön test uygulanan öğrenciler araştırmanın yapıldığı okulda eğitimlerini sürdürmektedirler. Ön test sonucunda elde edilen verilerin alfa kat sayısı değeri hesaplanmıştır. Cronbach Alfa kat sayısı değerinin hesaplanması araştırma süreçlerinde kullanılan ölçeklerin güvenilirliğinin belirlenmesinde önemli bir etkendir (Bademci, 2006, s. 438; Kula Kartal ve Mor Dirlik, 2016, s. 1869). Yapılan hesaplama sonucunda Cronbach Alfa değeri ,733 olarak bulunmuştur. Bu analiz sonucunda ölçekte yer alan 2. ve 10. maddelerin çıkarllması gerektiği görülmüştür. 2. ve 10. maddeler ölçekten çıkarıldıktan sonra yapılan hesaplamada ise Cronbach Alfa değeri ,840 olarak bulunmuştur. Bu nedenle başlangıç aşamasından toplamda 30 olan madde sayısı 28'e düşürülmüştür. Verilerin analizi aşamasında 2. ve 10. maddeler değerlendirmeye alınmamıştır. Ölçekte yer alan maddelerin numarası bu işleme göre yeniden tanımlanmış ve maddelerin numara sıralaması bu şekilde ilerletilmiştir.

$\mathrm{Bu}$ araştırmada alfa kat sayısı değerinin ,840 şeklinde bulunması, kullanılan ölçeğin " $0,80 \leq \alpha<1,00$ " aralı̆̆ında yüksek güvenilirliğinin göstergesi niteliğindedir (Kayış, 2010, s. 405). Bu durum araştırmanın güvenilirliğine olumlu yönde katkı sağlamaktadır.

İkinci aşamada ise ölçekteki yer alan maddelerin değişkenliklerinin gruplandırılabilmesi için açımlayıcı faktör analizi uygulanmıştır (Kalayc1, 2010, s. 321). Yapılan faktör analizi sonucunda KMO değeri ,768 olarak tespit edilmiştir:

Kalayc1 (2010, s. 322) KMO değerinin kabul edilebilirliğinde 0,5 değerinden yüksekliğin önemli olduğunu belirtir. Yapılan faktör analizi sonucunda toplamda yedi faktör grubu oluşmuştur. Elde edilen bu faktörler varyansın \% 69,893'ünü açıklamaktadır. 1. faktör 14, 2. faktör 5, 3. faktör 1, 4. faktör 3, 5. faktör 3, 6. ve 7. faktörler birer maddeden oluşmaktadır.

\section{Verilerin Analizi}

$\mathrm{Bu}$ çalışmada verilerin değerlendirilmesinde nicel araștırma yöntemlerinden yararlanılmıştır. Bu doğrultuda sosyal medya uygulamalarının öğrencilerin akademik ve iletişim becerilerine etkisinin belirlenebilmesi amacıyla hazırlanan beşli likert tipi tutum ölçeğinden elde edilen veriler analiz edilmiştir. Araştırmada değerlendirmeye esas alınan değişkenler sınıf düzeyi ve cinsiyettir. Bölümlerin oransal dağılım durumu sebebiyle bu değişkenin etkisi incelenmemiştir. Bu doğrultuda verilerin değerlendirilme aşamasında t testi, Anova (Varyans analizi), frekans (f) ve yüzdelik oran (\%) hesaplamaları yapılmıştır. Bu hesaplamaların yapılmasında Spss 20 programından yararlanılmışır.

$\mathrm{Bu}$ araştırmada kullanılan ölçekte yer alan maddeler üç temel özellik açısından sıralanmıştır. Bu özellikler sosyal medya uygulamalarının iletişim becerilerine etkisine yönelik ifadeler, sosyal medya uygulamalarının akademik becerilere etkisine yönelik ifadeler ve sosyal medya uygulamalarının kullanımına 
yönelik genel bilgiler şeklindedir. 2, 4, 5, 6, 7, 8, 9, 10, 11, 12, 13, 14, 15, 18, 26. maddeler sosyal medya uygulamalarının iletişim becerilerine etkisine yönelik ifadeleri; 16, 17, 19, 20, 21, 22, 23, 24, 25. maddeler ise sosyal medya uygulamalarının akademik becerilere etkisine yönelik ifadeleri içermektedir. 1, 3, 27, 28. maddeler sosyal medya uygulamalarının kullanımına yönelik genel bilgileri içermektedir.

Araştırmada öğrencilerin verdikleri cevapların cinsiyet değişkeni yönünden incelenmesinde parametrik hipotez testlerinden olan Bağımsız İki Örnek T-Testi (Independent-Samples T-Test) uygulanmıştır. Bu özelliği ile $\mathrm{t}$ testi iki grup arasındaki ortalamaların farklılıklarının tespit edilmesinde kullanılmaktadır (Ak, 2010, s. 74). Öğrencilerin verdikleri cevapların sınıf düzeyleri açısından incelenmesinde ise Anova'dan (varyans analizi) yararlanılmışır. Anova, ikiden fazla sayıdaki grubun ortalamalarının farklılıklarının belirlenmesinde kullanılabilen bir yöntemdir (Antalyalı, 2010, s. 131). Bu duruma ek olarak araştırmaya katılan öğrencilerin verdikleri cevaplar maddeler özelinde frekans (f) ve yüzdelik (\%) dilimler açısından da analiz edilmiştir. Bu değerlendirme sırasında öğrencilerin maddelere verdikleri cevapların, genel katılımcı sayısına oranları göz önünde bulundurulmuştur. Bu aşamada değerlendirmede açılık sağlanabilmesi için kesinlikle katıliyorum, katıllyorum seçenekleri bir arada değerlendirilerek katıllyorum şeklinde; benzer şekilde kesinlikle katılmıyorum, katılmıyorum seçenekleri de bir arada değerlendirilerek katılmıyorum şeklinde hesaplanmıştır. Bu vasıta ile öğrencilerin ilgili maddelere katılma/katılmama durumlarının belirlenmesi amaçlanmışır. Ayrıca yapılan analizlere ait veriler tablolar şeklinde de sunularak bu yönde verilerin düzenli okunması sağlanmaya çalısılmıştır. Yapılan analizler sonucunda elde edilen verilerden $\mathrm{p}<$ 0,05 düzeyinde anlamlı farklılık oluşturan (Ak, 2010, s. 81) maddeler yorumlanmıştır. Tablolarda sadelik sağlanması açısından anlamlı farklılık oluşturan maddelere yer verilmiştir. Araştırmanın sonuç bölümünde öğrencilerin çoğunluğunun (> \% 50)fikir birliğinde olduğu konular yorumlanmıştır. Sonuç bölümündeki “ögrenciler" ifadesi ile belirtilmek istenen grup "bu araştırmaya katılan öğrencilerdir".

\section{Bulgular}

Araştırma sürecinde sosyal medya uygulamalarının öğrencilerin akademik ve iletişsim becerilerine etkisinin tespit edilmesine yönelik hazırlanan ölçekte yer alan maddelere verilen cevapların oranlarına ait bilgiler Tablo 1'de sunulmuştur:

Tablo 1. Maddelere verilen cevaplarn ortalamalar

\begin{tabular}{|c|c|c|c|c|c|c|c|c|c|c|}
\hline \multirow[t]{2}{*}{ Madde } & $\%$ & Frekans & & Frekans & $\%$ & Frekans & $\%$ & Frekans & & Frekans \\
\hline & \multicolumn{2}{|c|}{ K. Katılmiyorum } & \multicolumn{2}{|c|}{ Katılmiyorum } & \multicolumn{2}{|c|}{ Karars1z1m } & \multicolumn{2}{|c|}{ Kat1lyorum } & \multicolumn{2}{|c|}{ K. Katilyorum } \\
\hline 1 & 14,1 & 13 & 2,2 & 2 & 5,4 & 5 & 39,1 & 36 & 39,1 & 36 \\
\hline 2 & 10,9 & 10 & 9,8 & 9 & 33,7 & 31 & 28,3 & 26 & 17,4 & 16 \\
\hline 3 & 19,8 & 18 & 20,9 & 19 & 11 & 10 & 27,5 & 25 & 20,9 & 19 \\
\hline 4 & 13,2 & 12 & 6,6 & 6 & 40,7 & 37 & 19,8 & 18 & 19,8 & 18 \\
\hline 5 & 15,2 & 14 & 19,6 & 18 & 22,8 & 21 & 25 & 23 & 17,4 & 16 \\
\hline 6 & 11,2 & 10 & 13,5 & 12 & 39,3 & 35 & 27 & 24 & 9 & 8 \\
\hline 7 & 15,4 & 14 & 25,3 & 23 & 34,1 & 31 & 18,7 & 17 & 6,6 & 6 \\
\hline 8 & 23,9 & 22 & 21,7 & 20 & 25 & 23 & 18,5 & 17 & 10,9 & 10 \\
\hline 9 & 24,4 & 22 & 26,7 & 24 & 20 & 18 & 21,1 & 19 & 7,8 & 7 \\
\hline 10 & 13,3 & 12 & 12,2 & 11 & 12,2 & 11 & 26,7 & 24 & 35,6 & 32 \\
\hline 11 & 25 & 23 & 22,8 & 21 & 25 & 23 & 14,1 & 13 & 13 & 12 \\
\hline 12 & 14,6 & 13 & 13,5 & 12 & 20,2 & 18 & 28,1 & 25 & 23,6 & 21 \\
\hline 13 & 9,8 & 9 & 10,9 & 10 & 27,2 & 25 & 28,3 & 26 & 22,8 & 21 \\
\hline 14 & 13,2 & 12 & 15,4 & 14 & 16,5 & 15 & 31,9 & 29 & 23,1 & 21 \\
\hline 15 & 9,9 & 9 & 6,6 & 6 & 17,6 & 16 & 40,7 & 37 & 25,3 & 23 \\
\hline 16 & 2,2 & 2 & 20 & 18 & 26,7 & 24 & 30 & 27 & 21,1 & 19 \\
\hline 17 & 14,1 & 13 & 22,8 & 21 & 29,3 & 27 & 19,6 & 18 & 14,1 & 13 \\
\hline 18 & 6,5 & 6 & 20,7 & 19 & 27,2 & 25 & 22,8 & 21 & 22,8 & 21 \\
\hline 19 & 4,3 & 4 & 12 & 11 & 19,6 & 18 & 33,7 & 31 & 30,4 & 28 \\
\hline 20 & 12,1 & 11 & 14,3 & 13 & 25,3 & 23 & 27,5 & 25 & 20,9 & 19 \\
\hline 21 & 11,1 & 10 & 10 & 9 & 16,7 & 15 & 37,8 & 34 & 24,4 & 22 \\
\hline 22 & 15,4 & 14 & 27,5 & 25 & 22 & 20 & 18,7 & 17 & 16,5 & 15 \\
\hline 23 & 16,5 & 15 & 33 & 30 & 28,6 & 26 & 13,2 & 12 & 8,8 & 8 \\
\hline 24 & 24,4 & 22 & 25,6 & 23 & 22,2 & 20 & 20 & 18 & 7,8 & 7 \\
\hline 25 & 21,1 & 19 & 13,3 & 12 & 42,2 & 38 & 14,4 & 13 & 8,9 & 8 \\
\hline 26 & 8,9 & 8 & 11,1 & 10 & 26,7 & 24 & 33,3 & 30 & 20 & 18 \\
\hline 27 & 15,4 & 14 & 17,6 & 16 & 23,1 & 21 & 25,3 & 23 & 18,7 & 17 \\
\hline 28 & 16,5 & 15 & 16,5 & 15 & 19,8 & 18 & 19,8 & 18 & 27,5 & 25 \\
\hline
\end{tabular}




\section{Sosyal medya uygulamalatının iletişim becerilerine etkisine yönelik maddelerin analizi}

Araştırma formunda yer alan ikinci ifade "Sosyal medya uygulamalarını kullanmak özgüvenimi olumlu yönde geliştirir." şeklindedir. Bu ifadeye araştırmaya katılan öğrencilerin verdikleri cevaplar incelendiğinde $\%$ 10,9 kesinlikle katılmiyorum, \% 9,8 katılmiyorum, \% 33,7 kararsızım, \% 28,3 katiliyorum ve \% 17,4 oranında tamamen katılıyorum seçenekleri işaretlenmiştir. Bu veriler yorumlandığında araştırmaya katılan öğrencilerin en çok yoğunlaştıkları seçeneğin \% 45,7 oranla kattlıyorum yönünde olduğu görülmektedir.

Araştırma formunda yer alan dördüncü ifade "Sosyal medya uygulamalarını kullanmak değerler sistemimi olumlu etkiler." şeklindedir. Bu ifadeye araștırmaya katılan öğrencilerin verdikleri cevaplar incelendiğinde $\% 13,2$ kesinlikle katılmıyorum, \% 6,6 katılmıyorum, \% 40,7 kararsızım, \% 19,8 katıliyorum ve $\% 19,8$ oranında tamamen kattlıyorum seçenekleri işaretlenmiştir. Bu veriler yorumlandığında araştırmaya katılan öğrencilerin en çok yoğunlaştıkları seçeneğin \% 40,7 oranla kararsızım yönünde olduğu görülmektedir. Ayrıca öğrencilerin \% 39,6’sının sosyal medya uygulamalarının değerler sistemini olumlu etkilediğini belirttikleri söylenebilir.

Araştırma formunda yer alan beşinci ifade "Sosyal medyada tanınırlı̆ı̆ yüksek olanların özgüvenleri de yüksektir.” şeklindedir. Bu ifadeye araştırmaya katılan öğrencilerin verdikleri cevaplar incelendiğinde \% 15,2 kesinlikle katılmiyorum, \% 19,6 katilmıyorum, \% 22,8 kararsızım, \% 25 kat1lyorum ve \% 17,4 oranında tamamen katılıyorum seçenekleri işaretlenmiştir. Bu veriler yorumlandığında araştırmaya katılan öğrencilerin en çok yoğunlaştıkları seçeneğin \% 42,4 oranla katıllyorum yönünde olduğu görülmektedir. Bu durum sosyal medyada tanınırlı̆̆ı özgüveni doğrudan etkilediği konusuna katılan öğrencilerin oranının diğer görüşlere göre (katılmıyorum/kararsızım) daha fazla olduğunu göstermektedir.

Araştırma formunda yer alan altıncı ifade "Sosyal medyada tanınırlık öğrenci için sosyal bir statü ifade etmez." şeklindedir. Bu ifadeye araştırmaya katılan öğrencilerin verdikleri cevaplar incelendiğinde \% 11,2 kesinlikle katılmıorum, \% 13,5 katılmıyorum, \% 39,3 kararsızım, \% 27 katilıorum ve \% 9 oraninda tamamen katılıyorum seçenekleri işaretlenmiştir. $\mathrm{Bu}$ veriler yorumlandığında araştırmaya katılan öğrencilerin en çok yoğunlaştıkları seçeneğin \% 39,3 oranla kararsızım yönünde olduğu görülmektedir.

Araştırma formunda yer alan yedinci ifade "Sosyal medya uygulamalarını kullanmak öğrencinin ailesi ile iletişimini olumlu etkiler." şeklindedir. Bu ifadeye araştırmaya katılan öğrencilerin verdikleri cevaplar incelendiğinde \% 15,4 kesinlikle katılmıyorum, \% 25,3 katılmıyorum, \% 34,1 kararsızım, \% 18,7 katılıyorum ve $\%$ 6,6 oranında tamamen katılıyorum seçenekleri işaretlenmiştir. Bu veriler yorumlandığında araştırmaya katılan öğrencilerin en çok yoğunlaştıkları seçeneğin \% 40,7 oranla katılmıyorum yönünde olduğu görülmektedir. Bu durum katılımcılar arasında sosyal medya uygulamalarının öğrenci-aile etkileşimi olumlu etkilediğini düşünmeyenlerin oranının diğer görüşlere göre (katılıyorum/kararsızım) daha fazla olduğunu göstermektedir.

Araştırma formunda yer alan sekizinci ifade "Sosyal medya uygulamalarını kullanmak öğrencinin çevresi ile iletişimini olumsuz etkiler." şeklindedir. Bu ifadeye araştırmaya katılan öğrencilerin verdikleri cevaplar incelendiğinde \% 23,9 kesinlikle katılmıorum, \% 21,7 katılmıyorum, \% 25 kararsızım, \% 18,5 katıllyorum ve \% 10,9 oranında tamamen katıliyorum seçenekleri işaretlenmiştir. $\mathrm{Bu}$ veriler yorumlandığında araştırmaya katılan öğrencilerin en çok yoğunlaştıkları seçenek \% 45,6 oranla katılmıyorum yönündedir. Bu durum araştırmaya katılan öğrenciler arasında sosyal medya uygulamalarının öğrencilerin çevresi ile iletişimini olumsuz etkilediğini düşünmeyenlerin oranının diğer görüşlere göre (katıliyorum/kararsızım) daha fazla olduğunu göstermektedir.

Araştırma formunda yer alan dokuzuncu ifade "Sosyal medya uygulamalarını kullanmamak öğrencinin arkadaşları ile iletişimini olumsuz etkiler." şeklindedir. Bu ifadeye araştırmaya katılan öğrencilerin verdikleri cevaplar incelendiğinde \% 24,4 kesinlikle katılmıyorum, \% 26,7 katılmıyorum, \% 20 kararsızım, \% 21,1 katıllyorum ve $\% 7,8$ oranında tamamen katılıyorum seçenekleri işaretlenmiştir. Bu veriler yorumlandığında araştırmaya katılan öğrencilerin en çok yoğunlaştıkları seçenek \% 51,1 oranla katılmıyorum yönündedir. Bu durum araştırmaya katılan öğrencilerin çoğunluğunun sosyal medya uygulamalarını kullanmamanın arkadaşlar ile iletişimi olumsuz etkilediği konusuna katılmadığını göstermektedir.

Araştırma formunda yer alan onuncu ifade "Sosyal medya uygulamalarını kullanan öğrenciler, kullanmayan öğrencilere göre öğretmenleri tarafindan daha çok tanınırlar." şeklindedir. Bu ifadeye araştırmaya katılan öğrencilerin verdikleri cevaplar incelendiğinde \% 13,3 kesinlikle katılmıyorum, \% 12,2 katılmıyorum, \% 12,2 kararsızım, \% 26,7 katilıyorum ve \% 35,6 oranında tamamen katıllyorum seçenekleri 
işaretlenmiştir. $\mathrm{Bu}$ veriler yorumlandığında araştırmaya katılan öğrencilerin en çok yoğunlaştıkları seçeneğin \% 62,3 oranla katıllyorum yönünde olduğu görülmektedir. Bu durum araştırmaya katılan öğrencilerin çoğunluğunun sosyal medya uygulamalarını kullanan öğrencilerin öğretmenleri tarafindan daha çok tanındığını düşündüklerini göstermektedir.

Araștırma formunda yer alan on birinci ifade "Sosyal medya uygulamalarını kullanmanın dil becerilerimin gelişimini olumlu yönde etkilediğini düşünüyorum." şeklindedir. Bu ifadeye araştırmaya katılan öğrencilerin verdikleri cevaplar incelendiğinde \% 25 kesinlikle katılmıyorum, \% 22,8 katılmıyorum, $\% 25$ kararsızım, \% 14,1 katıliyorum ve \% 13 oranında tamamen katıllyyorum seçenekleri işaretlenmiştir. Bu veriler yorumlandığında araştırmaya katılan öğrencilerin en çok yoğunlaştıkları seçenek \% 47,8 oranla katılmıyorum yönündedir. Bu durum sosyal medya uygulamalarını kullanmanın dil becerilerinin gelişimini olumlu etkilediğini düşünmeyen öğrencilerin oranının diğer görüşlere göre (katıllyorum/kararsızım) daha fazla olduğunu göstermektedir.

Araştırma formunda yer alan on ikinci ifade "Sosyal medya uygulamalarını kullanmanın dinlediğimi ve izlediğimi anlama becerilerimi olumlu yönde geliştirdiğini düşünüyorum." şeklindedir. Bu ifadeye araştırmaya katılan öğrencilerin verdikleri cevaplar incelendiğinde \% 14,6 kesinlikle katılmıyorum, \% 13,5 katılmıorum, \% 20,2 kararsızım, \% 28,1 katıllyorum ve \% 23,6 oranında tamamen katıllyorum seçenekleri işaretlenmiştir. Bu veriler yorumlandığında araştırmaya katılan öğrencilerin en çok yoğunlaştıkları seçenek \% 51,7 oranla kattllyorum yönündedir. Bu durum öğrencilerin çoğunluğunun sosyal medya uygulamalarını kullanmanın dinleme-anlama becerilerini olumu yönde geliştirdiğini düşündüklerini göstermektedir.

Araştırma formunda yer alan on üçüncü ifade "Sosyal medya uygulamalarını kullanmanın okuduğumu anlama becerilerimi olumlu yönde geliştirdiğini düşünüyorum.” şeklindedir. Bu ifadeye araştırmaya katılan öğrencilerin verdikleri cevaplar incelendiğinde \% 9,8 kesinlikle katılmıorum, \% 10,9 katılmıorum, \% 27,2 kararsızım, \% 28,3 katıliyorum ve \% 22,8 oranında tamamen kattlıyorum seçenekleri işaretlenmiştir. $\mathrm{Bu}$ veriler yorumlandığında araştırmaya katılan öğrencilerin en çok yoğunlaştıklanı seçenek \% 51,1 oranla katıllyorum yönündedir. Bu durum öğrencilerin çoğunluğunun sosyal medya uygulamalarını kullanmanın okuma-anlama becerilerini olumu yönde geliştirdiğini düşündüklerini göstermektedir.

Araştırma formunda yer alan on dördüncü ifade "Sosyal medya uygulamalarını kullanmanın kendimi yazılı olarak ifade etme becerilerimi olumlu yönde geliştirdiğini düşünüyorum." şeklindedir. Bu ifadeye araştırmaya katılan öğrencilerin verdikleri cevaplar incelendiğinde \% 13,2 kesinlikle katılmıyorum, \% 15,4 katılmıorum, \% 16,5 kararsızım, \% 31,9 katıllyorum ve \% 23,1 oranında tamamen katıllyorum seçenekleri işaretlenmiştir. Bu veriler yorumlandığında araştırmaya katılan öğrencilerin en çok yoğunlaştıkları seçenek \% 55 oranla katılıyorum yönündedir. Bu durum araştırmaya katılan öğrencilerin genelinin sosyal medya uygulamalarını kullanmanın yazılı ifade becerilerini olumlu geliştirdiğini düşündüklerini göstermektedir.

Araştırma formunda yer alan on beşinci ifade "Sosyal medya uygulamalarını kullanmanın kendimi sözlü olarak ifade etme becerilerimi olumlu yönde geliştirdiğini düşünüyorum." şeklindedir. Bu ifadeye araştırmaya katılan öğrencilerin verdikleri cevaplar incelendiğinde \% 9,9 kesinlikle katılmıyorum, \% 6,6 katılmıorum, \% 17,6 kararsızım, \% 40,7 katıllyorum ve \% 25,3 oranında tamamen katıllıorum seçenekleri işaretlenmiştir. Bu veriler yorumlandığında araştırmaya katılan öğrencilerin en çok yoğunlaştıkları seçenek \% 66 oranla katıllyorum yönündedir. Bu durum araştırmaya katılan öğrencilerin çoğunluğunun sosyal medya uygulamalarını kullanmanın sözlü ifade becerilerini olumlu geliştirdiğini düşündüklerini göstermektedir.

Araştırma formunda yer alan on sekizinci ifade "Sosyal medya uygulamalarını kullanmak öğrencinin öğretmenleri ile iletişimini olumlu etkiler." şeklindedir. Bu ifadeye araştırmaya katılan öğrencilerin verdikleri cevaplar incelendiğinde $\%$ 6,5 kesinlikle katılmıorum, $\% 20,7$ katılmıyorum, $\% 27,2$ kararsızım, $\% 22,8$ katıllyorum ve $\% 22,8$ oranında tamamen katıllyorum seçenekleri işaretlenmiştir. $\mathrm{Bu}$ veriler yorumlandığında araştırmaya katılan öğrencilerin en çok yoğunlaştıkları seçenek \% 45,6 oranla katıliyorum yönündedir. Bu durum araştırmaya katılan öğrenciler arasında sosyal medya uygulamalarını kullanmanın öğretmenlerle olumlu iletişim kurmaya katkı sağladığı görüşünde olanların sayısının diğer görüşlere göre (katılmıorum/kararsızım) daha fazla olduğunu göstermektedir.

Araştırma formunda yer alan yirmi altıncı ifade "Bu uygulamalardan edindiğim bilgileri ders sürecinde sınıftaki arkadaşlarımla, öğretmenimle paylaşırım.” şeklindedir. Bu ifadeye araştırmaya katılan öğrencilerin verdikleri cevaplar incelendiğinde $\%$ 8,9 kesinlikle katılmıorum, \% 11,1 katılmıyorum, \% 26,7 kararsızım, $\% 33,3$ katıllyorum ve $\% 20$ oranında tamamen katıliyorum seçenekleri işaretlenmiştir. Bu veriler yorumlandığında araştırmaya katılan öğrencilerin en çok yoğunlaştıkları seçenek \% 53,3 oranla katılıyorum 
yönündedir. $\mathrm{Bu}$ durum araştırmaya katılan öğrencilerin çoğunluğunun sosyal medya uygulamaları vasıtasıyla edindikleri bilgileri arkadaşları, öğretmenleri ile paylaştıklarını belirttiklerini göstermektedir.

\section{Sosyal medya uygulamalarını akademik becerilere etkisine yönelik maddelerin analizi}

Araştırma formunda yer alan on altıncı ifade "Sosyal medya uygulamalarını kullanmanın derslerimde bana olumlu yönde katkısı yoktur." şeklindedir. Bu ifadeye araştırmaya katılan öğrencilerin verdikleri cevaplar incelendiğinde \% 2,2 kesinlikle katılmıorum, \% 20 katılmıyorum, \% 26,7 kararsızım, \% 30 katıllyorum ve \% 21,1 oranında tamamen katıliyorum seçenekleri işaretlenmiştir. $\mathrm{Bu}$ veriler yorumlandığında araştırmaya katılan öğrencilerin en çok yoğunlaştıkları seçenek \% 51,1 oranla katıllyorum yönündedir. $\mathrm{Bu}$ durum araştırmaya katılan öğrencilerin çoğunluğunun sosyal medya uygulamalarının derslere olumlu yönde katkı sağladığı görüşünü onaylamadıklarını göstermektedir.

Araştırma formunda yer alan on yedinci ifade "Sosyal medya uygulamalarını denetimli kullanmak öğrencinin akademik gelişimine olumlu yönde etki yapar." şeklindedir. Bu ifadeye araştırmaya katılan öğrencilerin verdikleri cevaplar incelendiğinde \% 14,1 kesinlikle katılmıorum, \% 22,8 katılmıyorum, \% 29,3 kararsızım, \% 19,6 katıllyorum ve \% 14,1 oranında tamamen katıliyorum seçenekleri işaretlenmiştir. Bu veriler yorumlandığında araştırmaya katılan öğrencilerin en çok yoğunlaştıkları seçeneğin \% 36,9 oranla katılmıyorum yönünde olduğu görülmektedir. Oran olarak düşük olmasina karşın bu sonucun on yedinci ifadeye verilen cevaplarla benzer yönde olduğu söylenebilir.

Araştırma formunda yer alan on dokuzuncu ifade "Sosyal medya uygulamalarını eğitim amaçlı kullanmak öğrencinin akademik gelişimine olumlu yönde etki yapar." şeklindedir. Bu ifadeye araştırmaya katılan öğrencilerin verdikleri cevaplar incelendiğinde \% 4,3 kesinlikle katılmıyorum, \% 12 katılmıyorum, $\%$ 19,6 kararsızım, \% 33,7 kat1liyorum ve \% 30,4 oranında tamamen katiliyorum seçenekleri işaretlenmiştir. Bu veriler yorumlandığında araştırmaya katılan öğrencilerin en çok yoğunlaştıkları seçenek \% 64,1 oranla katılıyorum yönündedir. Burada özellikle sosyal medya uygulamalarının eğitim amaçlı kullanılması ifadesi önemlidir. Çünkü on altıncı ve on yedinci ifadelere verilen cevaplardan farklı olarak bu ifade de araştırmaya katılan öğrencilerin çoğunluğunun bu uygulamaların eğitsel amaçlı kullanıldığında akademik yönden olumlu katkı sağlayacağını belirttikleri görülmektedir.

Araştırma formunda yer alan yirminci ifade "Sosyal medya uygulamalarını kullanmanın kültürel bilgi birikimimi olumlu yönde geliştirdiğini düşünüyorum." şeklindedir. Bu ifadeye araştırmaya katılan öğrencilerin verdikleri cevaplar incelendiğinde \% 12,1 kesinlikle katılmıorum, \% 14,3 katılmıyorum, \% 25,3 kararsızım, \% 27,5 katıllyorum ve \% 20,9 oranında tamamen katıllyorum seçenekleri işaretlenmiştir. $\mathrm{Bu}$ veriler yorumlandığında araştırmaya katılan öğrencilerin en çok yoğunlaştıkları seçenek \% 48,4 oranla katıllyorum yönündedir. Bu durum araştırmaya katılan öğrenciler arasında sosyal medya uygulamalarını kullanmanın kültürel bilgi birikimine olumlu katkı sağladığı görüşünde olanların sayısının diğer görüsslere göre (katılmıyorum/kararsızım) daha fazla olduğunu göstermektedir.

Araştırma formunda yer alan yirmi birinci ifade "Sosyal medya uygulamalarını kullanarak evrensel düzeyde bilgiye erişebiliyorum.” şeklindedir. Bu ifadeye araştırmaya katılan öğrencilerin verdikleri cevaplar incelendiğinde \% 11,1 kesinlikle katılmıorum, \% 10 katılmıyorum, \% 16,7 kararsızım, \% 37,8 katıllyorum ve $\% 24,4$ oranında tamamen katıllyorum seçenekleri işaretlenmiştir. Bu veriler yorumlandığında araştırmaya katılan öğrencilerin en çok yoğunlaştıkları seçenek \% 62,2 oranla katılıyorum yönündedir. Bu durum araştırmaya katılan öğrencilerin çoğunluğunun sosyal medya uygulamaları vasıtası ile evrensel düzeyde bilgiye erişebildiklerini belirttiklerini göstermektedir.

Araştırma formunda yer alan yirmi ikinci ifade "Sosyal medya uygulamalarını kullanmanın yaratıcı düşünme becerilerime olumlu yönde etkisinin olduğunu düşünmüyorum.” şeklindedir. Bu ifadeye araştırmaya katılan öğrencilerin verdikleri cevaplar incelendiğinde \% 15,4 kesinlikle katılmıyorum, \% 27,5 katılmıorum, \% 22 kararsızım, \% 18,7 katıliyorum ve \% 16,5 oranında tamamen katıllyorum seçenekleri işaretlenmiştir. Bu veriler yorumlandığında araştırmaya katılan öğrencilerin en çok yoğunlaştıkları seçenek $\% 47,5$ oranla katılmıyorum yönündedir. Bu durum araştırmaya katılan öğrenciler arasında sosyal medya uygulamalarını kullanmanın yaratıcı düşünme becerilerine olumlu katkı sağlamadığı görüşünü desteklemeyenlerin sayısının diğer görüşlere göre (katllıorum/kararsızım) daha fazla olduğunu göstermektedir.

Araştırma formunda yer alan yirmi üçüncü ifade "Sosyal medya uygulamalarını kullanmanın eleştirel düşünme becerilerime olumlu yönde etkisinin olduğunu düşünmüyorum.” şeklindedir. Bu ifadeye 
araştırmaya katılan öğrencilerin verdikleri cevaplar incelendiğinde \% 16,5 kesinlikle katılmıorum, \% 33 katılmıyorum, \% 28,6 kararsızım, \% 13,2 katılıyorum ve \% 8,8 oranında tamamen katilıyorum seçenekleri işaretlenmiştir. Bu veriler yorumlandığında araştırmaya katılan öğrencilerin en çok yoğunlaştıkları seçenek $\%$ 49,5 oranla katılmıyorum yönündedir. Bu durum araştırmaya katılan öğrenciler arasında sosyal medya uygulamalarını kullanmanın eleştirel düşünme becerilerine olumlu katk1 sağlamadığ1 görüşünü desteklemeyenlerin sayısının diğer görüşlere göre (katılıyorum/kararsızım) daha fazla olduğunu göstermektedir.

Araştırma formunda yer alan yirmi dördüncü ifade "Sosyal medya uygulamalarını kullanmanın araştırma becerilerime olumlu yönde etkisinin olduğunu düşünmüyorum." şeklindedir. $\mathrm{Bu}$ ifadeye araştırmaya katılan öğrencilerin verdikleri cevaplar incelendiğinde \% 24,4 kesinlikle katılmıyorum, \% 25,6 katılmıyorum, \% 22,2 kararsızım, \% 20 katıllyorum ve \% 7,8 oranında tamamen katıllyorum seçenekleri işaretlenmiştir. Bu veriler yorumlandığında araştırmaya katılan öğrencilerin en çok yoğunlaştıkları seçenek $\% 50$ oranla katılmıyorum yönündedir. Bu durum araştırmaya katılan öğrenciler arasında sosyal medya uygulamalarını kullanmanın araştırma becerilerine olumlu katkı sağlamadığı görüşünü desteklemeyenlerin sayısının diğer görüşlere göre (katılıyorum/kararsızım) daha fazla olduğunu göstermektedir. Burada özellikle yaratıcı düşünme, eleştirel düşünme, araştırma becerileri alanlarında verilen cevapların benzer ve katılmıyorum yönünde daha fazla olması dikkat çekmektedir. Bu durumun araştırmaya katılan öğrencilere göre sıralanan beceriler açısından sosyal medya uygulamalarının katkı sağlayabileceği düşüncesine işaret edebileceği söylenilebilir.

Araştırma formunda yer alan yirmi beşinci ifade "Bu uygulamalar vasıtası ile elde edilen bilgiler genelde güvenilirdir." şeklindedir. Bu ifadeye araştırmaya katılan öğrencilerin verdikleri cevaplar incelendiğinde $\%$ 21,1 kesinlikle katılmıyorum, \% 13,3 katılmıyorum, \% 42,2 kararsızım, \% 14,4 katılıyorum ve $\% 8,9$ oranında tamamen katıliyorum seçenekleri işaretlenmiştir. Bu veriler yorumlandığında araştırmaya katılan öğrencilerin en çok yoğunlaştıkları seçenek \% 42,2 oranla kararsızlık yönündedir.

\section{Sosyal medya uygulamalarının kullanımına yönelik genel bilgileri içeren maddelerin analizi}

Araştırma formunda yer alan birinci ifade "Sosyal medya uygulamalarını genelde kullanırım." şeklindedir. Bu ifadeye araştırmaya katılan öğrencilerin verdikleri cevaplar incelendiğinde \% 14,1 kesinlikle katılmiyorum, \% 2 katılmiyorum, \% 5,4 kararsızım, \% 39,1 katıliyorum ve \% 39,1 oranında tamamen katıllyorum seçenekleri işaretlenmiştir. Bu veriler yorumlandığında araştırmaya katılan öğrencilerin $\% 78,2$ oranında katılıyorum yönünde cevap verdikleri görülmektedir. Bu durum araştırmaya katılan öğrencilerin çoğunluğunun sosyal medya uygulamalarını kullandıklarını belirttiklerini göstermektedir.

Araştırma formunda yer alan üçüncü ifade "Sosyal medya uygulamalarının kullanımında ebeveyn, öğretmen vb. denetimi gereklidir." şeklindedir. Bu ifadeye araştırmaya katılan öğrencilerin verdikleri cevaplar incelendiğinde \% 19,8 kesinlikle katılmıorum, \% 20,9 katılmıyorum, \% 11 kararsızım, \% 27,5 katıllyorum ve \% 20,9 oranında tamamen katllyorum seçenekleri işaretlenmiştir. Bu veriler yorumlandığında araştırmaya katılan öğrencilerin \% 48,4’ünün sosyal medya uygulamalarının kullanımında denetimin gerekli olduğunu ifade ettikleri görülmektedir.

Araştırma formunda yer alan yirmi yedinci ifade "Öğrencilerin bu tür uygulamaları kullanmaları sırasında ailelerin, kurumların vb. denetim yapması gerektiğini düşünüyorum.” şeklindedir. Bu ifadeye araştırmaya katılan öğrencilerin verdikleri cevaplar incelendiğinde \% 15,4 kesinlikle katılmıyorum, \% 17,6 katılmıyorum, \% 23,1 kararsızım, \% 25,3 katilıyorum ve \% 18,7 oranında tamamen katılıyorum seçenekleri işaretlenmiştir. Bu veriler yorumlandığında araştırmaya katılan öğrencilerin en çok yoğunlaştıkları seçenek $\% 44$ oranla katıliyorum yönündedir. Bu durum araștırmaya katılan öğrenciler arasında sosyal medya uygulamalarının kullanımında denetim yapılması gerekliliği görüşünde olanların sayısının diğer görüşlere göre (katıllyorum/kararsızım) daha fazla olduğunu göstermektedir. Bu yöndeki benzer ifadeleri içeren üçüncü maddeye verilen cevaplar ile bu maddeye verilen cevaplar arasında oransal açıdan yakınlık olmasının (\% 48,4/ \% 44) öğrencilerin cevaplarının güvenilirliğine olumlu etkisinin olduğu söylenilebilir.

Araştırma formunda yer alan yirmi sekizinci ifade "Öğrencilerin bu tür uygulamaları daha verimli kullanabilmeleri için öğretmenlerin, uzmanların vb. bilgilendirme ve rehberlik yapmaları gerektiğini düşünüyorum.” şeklindedir. Bu ifadeye araştırmaya katılan öğrencilerin verdikleri cevaplar incelendiğinde $\% 16,5$ kesinlikle katılmiyorum, \% 16,5 katılmıyorum, \% 19,8 kararsızım, \% 19,8 katıliyorum ve \% 27,5 oranında tamamen katılıyorum seçenekleri işaretlenmiştir. Bu veriler yorumlandığında araştırmaya katılan ögrencilerin en çok yoğunlaştıkları seçenek \% 47,3 oranla katıllyorum yönündedir. Bu durum araştırmaya katılan öğrenciler arasında sosyal medya uygulamalarının kullanımında rehberlik yapılması gerekliliği 
görüşünde olanların sayısının diğer görüşlere göre (kattlıyorum/kararsızım) daha fazla olduğu göstermektedir.

\section{Öğrencilerin cevaplarının cinsiyet de ğişkeni yönünden analizi}

Araştırma sürecinde sosyal medya uygulamalarının öğrencilerin akademik ve iletişim becerilerine etkisinin tespit edilmesine yönelik hazırlanan ölçekte yer alan maddelere verilen cevaplar cinsiyet değişkeni yönünden analiz edilmiştir. Analiz aşamasında bağımsız örneklemler $t$ testi kullanılmıştır. $\mathrm{P}<0,05$ aralığında anlamlı farklılık oluşturan maddelere Tablo 2'de yer verilerek bu maddeler yorumlanmıştır.

Tablo 2. Grup istatistikleri (Cinsiyet)

\begin{tabular}{llccc}
\hline & Cinsiyet & Say1 & Ort. & Sig. (2-tailed) \\
\hline \multirow{2}{*}{ Madde 7} & K1z & 23 & 2,3478 &, 022 \\
& Erkek & 68 & 2,8971 & \\
\multirow{2}{*}{ Madde 11} & Krz & 23 & 2,2174 & 0,49 \\
& Erkek & 69 & 2,8261 & \\
\hline
\end{tabular}

Yedinci maddedeki "Sosyal medya uygulamalarını kullanmak ögrencinin ailesi ile iletişimini olumlu etkiler." ifadesine yönelik veriler ilgili tablo vasıtasıyla incelendiğinde Sig. (2-tailed) değeri 0,22 , yani p < 0,05 aralığında anlamlıdır. Bu maddeye cevap veren katılımcılar arasında kız öğrencilerin cevaplarının ortalama değerinin 2,34, erkek öğrencilerin cevaplarının ortalama değerinin ise 2,89 olduğu görülmektedir. $\mathrm{Bu}$ veriler vasıtasıyla sosyal medya uygulamalarının öğrencilerin aileleri ile etkileşimini olumlu yönde etkilediği görüşünü araştırmaya katılan kız öğrencilerin erkek öğrencilere göre daha az destekledikleri söylenilebilir.

On birinci maddedeki "Sosyal medya uygulamalarını kullanmanın dil becerilerimin gelişimini olumlu yönde etkilediğini düşünüyorum.” ifadesine yönelik veriler ilgili tablo vasıtasıyla incelendiğinde Sig. (2tailed) değeri 0,49, yani $\mathrm{p}<0,05$ aralığında anlamlıdır. Bu maddeye cevap veren katılımclar arasında kız öğrencilerin cevaplarının ortalama değerinin 2,21, erkek öğrencilerin cevaplarının ortalama değerinin ise 2,82 olduğu görülmektedir. Bu durum sosyal medya uygulamalarının öğrencilerin dil becerilerinin gelişimini olumlu yönde etkilediği görüşünü araştırmaya katılan kız öğrencilerin erkek öğrencilere göre daha az desteklediklerini göstermektedir.

\section{Öğrencilerin cevaplarının sınıf düzeyi değişkeni yönünden analizi}

Araştırma sürecinde sosyal medya uygulamalarının öğrencilerin akademik ve iletişim becerilerine etkisinin tespit edilmesine yönelik hazırlanan ölçekte yer alan maddelere verilen cevaplar sınıf düzeyi değişkeni yönünden analiz edilmiştir. Analiz aşamasında Anova testi kullanılmıştır. P < 0,05 aralı̆̆ında anlamlı farklılık oluşturan 15. maddeye Tablo 3’te yer verilerek yorumlama yapılmıştır.

Tablo 3. Grup istatistikleri (Sinnf değģskeni)

\begin{tabular}{ccccc}
\hline & Sinif & Sayl & Ort. & Sig. \\
\hline \multirow{4}{*}{ Madde 15} & 9 & 44 & 3,8864 &, 003 \\
& 10 & 14 & 3,5714 & \\
& 11 & 9 & 4,4444 & \\
\hline
\end{tabular}

On beşinci maddedeki "Sosyal medya uygulamalarını kullanmanın kendimi sözlü olarak ifade etme becerilerimi olumlu yönde geliştirdiğini düşünüyorum." ifadesine yönelik veriler ilgili tablo vasitasılyla incelendiğinde Sig. değeri 0,003, yani $\mathrm{p}<0,05$ aralığında anlamlıdır. Bu maddeye cevap veren katılımcılar arasında dokuzuncu sınıf öğrencilerinin cevaplarının ortalama değerinin 3,88 , onuncu sınıf öğrencilerinin cevaplarının ortalama değerinin 3,57, on birinci sınıf öğrencilerinin cevaplarının ortalama değerinin 4,44, on ikinci sınıf öğrencilerinin cevaplarının ortalama değerinin 2,95 olduğu görülmektedir. Bu veriler vasıtasıyla sosyal medya uygulamalarının öğrencilerin sözlü ifade becerilerini olumlu yönde etkilediği görüşünü en az destekleyen grubun on ikinci sinıf ögrencilerinden, en fazla destekleyen grubun ise on birinci sınıf öğrencilerinden oluştuğu tespit edilmişsir. 


\section{Tartışma, Sonuç ve Öneriler}

$\mathrm{Bu}$ araştırmada sosyal medya uygulamalarının öğrencilerin akademik ve iletişim becerilerine etkisi, öğrencilerin görüşleri vasıtasıyla değerlendirilmiştir. Bu vasıta ile elde edilen bulgulardan ön plana çıan sonuçlar şu şekilde sıralanabilir:

- Araştırmaya katılan öğrencilerin çoğunluğunun sosyal medya uygulamalarını genel olarak kullandıkları,

- Öğrencilerin çoğunluğunun sosyal medya uygulamalarını kullanmamanın arkadaşları ile iletişimi olumsuz etkilediği konusuna katılmadığ1,

- Öğrencilerin çoğunluğunun sosyal medya uygulamalarını kullanan öğrencilerin öğretmenleri tarafından daha çok tanındığını düşündükleri,

- Öğrencilerin çoğunluğunun sosyal medya uygulamalarını kullanmanın dinleme-anlama becerilerini olumu yönde geliştirdiğini düşündükleri,

- Öğrencilerin çoğunluğunun sosyal medya uygulamalarını kullanmanın okuma-anlama becerilerini olumu yönde geliştirdiğini düşündükleri,

- Öğrencilerin genelinin sosyal medya uygulamalarını kullanmanın yazılı ifade becerilerini olumlu geliştirdiğini düşündükleri,

- Öğrencilerin çoğunluğunun sosyal medya uygulamalarını kullanmanın sözlü ifade becerilerini olumlu geliştirdiğini düşündükleri,

- Öğrencilerin çoğunluğunun sosyal medya uygulamalarının derslere olumlu yönde katkı sağladı̆̆1 görüşünü onaylamadıkları,

- Öğrencilerin çoğunluğunun sosyal medya uygulamalarının eğitsel amaçlı kullanıldığında akademik yönden olumlu katkı sağlayacağını düşündükleri,

- Öğrencilerin çoğunluğunun sosyal medya uygulamaları vasıtası ile evrensel düzeyde bilgiye erişebildiklerini düşündükleri,

- Öğrencilerin çoğunluğunun sosyal medya uygulamaları vasıtasıyla edindikleri bilgileri arkadaşları, öğretmenleri ile paylaştıklarını belirttikleri,

- Sosyal medya uygulamalarının öğrencilerin aileleri ile etkileşimini olumlu yönde etkilediği görüşünü araştırmaya katılan kız öğrencilerin erkek öğrencilere göre daha az destekledikleri,

- Sosyal medya uygulamalarının öğrencilerin dil becerilerinin gelişimini olumlu yönde etkilediği görüşünü araştırmaya katılan kız öğrencilerin erkek öğrencilere göre daha az destekledikleri,

- Sosyal medya uygulamalarının öğrencilerin sözlü ifade becerilerini olumlu yönde etkilediği görüşünü en az destekleyen grubun on ikinci sınıf ögrencilerinden, en fazla destekleyen grubun ise on birinci sınıf öğrencilerinden oluştuğu sonucuna ulaşılmıştır.

$\mathrm{Bu}$ araştırmanın sonuçlarına göre öğrencilerin sosyal medya uygulamalarını genel olarak kullandıkları görülmüştür. Bu konuyla ilgili olarak Küçükali (2016, s. 544) üniversite öğrencilerinin sosyal medya kullanımları üzerine yaptığı araştırmasında öğrencilerin genel olarak sosyal medyayı birer boş zaman aktivitesi olarak kullandığını belirtir ve öğrencilerin günlük ortalama sosyal medya kullanımlarının 3 saat olduğu tespit eder. Alican ve Saban (2013, s. 12) ise araştırmalarına katılan öğrencilerin \%89,2'sinin sosyal medya kullandığını belirtmektedirler. Vural ve Bat (2010, s. 3373) araştırmalarına katılan öğrencilerin çoğunun internette geçirdikleri sürenin genelde sosyal medya kullanımı şeklinde olduğunu ifade etmektedirler. Sosyal medya kullanım oranlarının ve sosyal medyaya ayrılan zamanın yüksek olmasının, kullanıcıların sosyal medyadan etkilenme durumlarını da yükseltebilmesi mümkündür. Bu durumun kullanıcıların iletişim becerilerini de etkilemesi muhtemeldir. Çünkü bu uygulamaların aynı zamanda iletişimsel amaçlar doğrultusunda da kullanılması sosyal medyanın bu yöndeki becerilere etkisini göstermesi açısından önemlidir. Nitekim bu konudaki araştırmasında Canbulat, Güven ve Çağlar (2017, s. 123) araştırmalarındaki katılımcıların çoğunluğunun sosyal medya dilini gençlik dili olarak tanımladıklarını ve bu dili kullandıklarını belirttiklerini tespit etmişlerdir.

Sosyal medyada bilgiye erişim ve erişilen bilginin paylaşılması konusu değerlendirildiğinde araştırmaya katılan öğrencilerin çoğunluğunun sosyal medya uygulamaları vasitasiyla evrensel düzeyde bilgiye erişebildiklerini ve bu bilgileri çevreleri ile paylaştıklarını belirttikleri görülmüştür. Ancak bilgiye erişim konusunda bilginin güvenilirliği önemli bir konumda bulunur. Nitekim bu durumu öğretim programlarında yer alan dijital yetkinlik ile açıklamak mümkündür (MEB, 2019, s. 5). Bilgi güvenliği konusuna dikkat çeken Özdemir (2015, s. 127), sosyal medyada genellikle doğru - yanlış veri konusunda net bilginin 
olmadığını belirtir. Kamiloğlu ve Yurttaş (2014, s. 147) araştırmalarında lise öğrencilerinin bilgi edinmede $\% 90$ interneti, $\% 70$ bir sosyal medya uygulamasını kullandığını belirtir ve bu uygulamalara kullanım yönünden nitelik kazandırılabileceğini de ifade eder. Bireylerin iletişime geçtikleri kişilerin gerçek ve güvenilir olduklarını bildiklerinde onların verdikleri bilgilerin de güvenilir olacağı konusunda bir ortam oluşabileceği düşünülebilir. Bu vasıtayla özellikle öğrencilerin güvenli bilgiye erişim, sorgulama gibi becerilerine olumlu katkı sağlanması mümkün olabilir.

Araştırma sürecinde elde edilen sonuçlar değerlendirildiğinde ön plana çıkan konulardan biri sosyal medya uygulamalarının eğitsel amaçlar doğrultusunda kullanılması durumudur. Bu durumun gelişmesinde ise sosyal medya kullanımının eğitsel amaçlar doğrultusunda olmasının önemine dikkat çekildiği söylenebilir. Çünkü araştırmaya katılan öğrencilerin çoğunluğunun bu tür uygulamaların sadece eğitsel amaçlar doğrultusunda kullanıldığında akademik gelişime olumlu etkisinin olacağı görüşünde oldukları, aksi durumda derslerine olumlu katkısının olmadığını düşündükleri tespit edilmiştir. Eğitsel nitelik kazandırılan sosyal medya uygulamalarının öğrencinin dil becerilerinin gelişiminde de etkili olacağı düşünülmektedir. Bu konuda Güneş (2013, s. 172) dil bilgisinin verilen iletileri anlama ve kendini ifade etme yönünden çok önemli olduğunu belirtir. Bu yönde yapılacak kapsamlı çalşsmalar öğrencilerin dil becerilerine olumlu veya olumsuz etkilerin tespit edilmesine katkı sağlayacaktır. Sarsar, Başbay ve Başbay (2015, s. 427) öğretim süreçlerinin planlanması aşamasında sosyal medya kullanımının göz önünde bulundurulması gerektiğine dikkat çekmektedirler. Görü Doğan (2015, s. 44) araştırmasına katılanların derslerin sosyal medya ile desteklenmesinin öğrenmeyi destekleyeceğini ifade ettiğini belirtir. Toğay, Akdur, Yetişken ve Bilici’ye (2013, s. 1) göre ise eğitim süreçlerinin sosyal medya ile desteklenmesi öğrencilerin akademik gelişimlerine katkı sağlamaktadır. Bu durumun dil becerilerinin geliştirilmesinde de geçerli olabileceği düşünülmektedir. Nitekim bu araştırma sonuçlarına göre öğrencilerin dil becerileri alanlarında verdikleri cevapların genel olarak olumlu yönde olduğu görülmektedir. Ayrıca öğrencilerin çoğunluğunun bu uygulamaları kullanmalarının arkadaşları ile iletişimlerini olumsuz etkilemediğini ve buna ek olarak bu uygulamaları kullanmanın öğretmenler tarafindan tanınmaya olumlu etkide bulunduğunu düşündükleri de tespit edilmiştir. Sıralanan bu sonuçlardan yola çıkarak araştırmacılar tarafından ilgili uygulamaların eğitsel açıdan değerlendirilmesi önemli görülmektedir.

Dinleme, okuma, yazma, konuşma (sözlü ifade) alanlarında (12,13, 14 ve 15. maddeler) öğrencilerin sosyal medya uygulamalarının etkilerine yönelik verdikleri cevapların oranlarının \% 50'nin üzerinde olduğu ve cevapların bu uygulamaların sıralanan beceriler açısından olumlu etkisine yönelik olduğu tespit edilmiştir. Ancak on birinci maddede bu durumun aksi yönde sonucun olduğu görülmektedir. Bu maddede uygulamaların dil becerilerinin gelişimini olumlu etkilediğini düşünmeyen öğrencilerin oranının $(\% 47,8)$ diğer görüşlere göre daha yüksek olduğu görülmektedir. Bu sonucun sebebi değerlendirildiğinde, dört temel dil becerisi alanında (dinleme, konuşma, okuma, yazma) benzer yönde cevaplar olmasına karşın, on birinci maddedeki cevabın farklı yönde olmasının, ilgili maddenin içeriğinde bulunan "dil becerileri" ifadesinden kaynaklandığ düşünülmektedir. Ancak diğer maddelerdeki benzer yöndeki sonuçların öğrencilerin görüşlerinin tespit edilmesi açısından yeterli olduğu düşünülmektedir. Bu açıdan araştırmaya katılan öğrencilerin çoğunluğunun dinleme, okuma, konuşma ve yazma dil becerileri açısından sosyal medya uygulamalarını olumlu olarak nitelendirdikleri söylenilebilir.

Araştırma sonuçları sınıf düzeyi ve cinsiyet değişkenleri açısından değerlendirildiğinde, sosyal medya uygulamalarının öğrencilerin sözlü ifade becerilerini olumlu yönde etkilediği görüșünü en az on ikinci sınıf ögrencilerinin, en fazla ise on birinci sınıf öğrencilerinin destekledikleri tespit edilmiştir. Ayrıca sosyal medya uygulamalarının öğrencilerin aileleri ile etkileşimini olumlu yönde etkilediği; öğrencilerin dil becerilerinin gelişimini olumlu yönde etkilediği görüşlerini kız öğrencilerin erkek öğrencilere oranla daha az destekledikleri görülmüştür. Bu açıdan iletişim ve dil becerilerinde cinsiyet değişkeni açısından oluşan farklılı̆ın nedenlerinin belirlenmesine yönelik çalışmaların yapılması araştırmacılara önerilmektedir. $\mathrm{Bu}$ çalışmaların konu alanına katkılarının olacağı düşünülmektedir.

Araştırma sonuçları sosyal medya uygulamalarının araştırmaya katılan öğrencilerin geneli tarafindan kullanıldı̆̆ını ve önemli bir iletişim aracı olarak tercih edildiğini göstermiştir. Eğitsel kullanımın olumlu boyutuna ek olarak sosyal medyada tanınırlığın öğretmenlerle iletişimde de önemli olduğu öğrencilerin dikkat çektikleri konulardandır. Bu nedenle öğretmenlerin bu uygulamaların etkin ve doğru kullanımında rehber konumunda olabilmesi için gerekli hizmet içi eğitimleri almalarının olumlu etkilerinin olacağı düşünülmektedir. 


\section{Etik Beyan}

"Sosyal Medya Uygulamalarmm Ögrencilerin Akademik ve İletişim Becerilerine Etkisinin Değerlendirilmesi: Mesleki ve Teknik. Anadolu Lisesi Örneği”" başlıklı çalışmanın yazım sürecinde bilimsel kurallara, etik ve alıntı kurallarına uyulmuş; toplanan veriler üzerinde herhangi bir tahrifat yapılmamış ve bu çalışma herhangi başka bir akademik yayın ortamına değerlendirme için gönderilmemiştir. Gerekli olan etik kurul izinleri Aksaray Üniversitesi İnsan Araştırmaları Etik Kurulu’nun 22.02.2021 tarih ve 2021/01-33 sayılı toplantısında alınmıştır.

\section{Kaynakça}

Ak, B. (2010). Parametrik hipotez testleri. İçinde Ş. Kalayc1 (Edt.), Spss uygulamal çok değişskenli istatistik teknikleri (ss. 73-82). Ankara: Asil Yayın Dağttım.

Antalyalı, Ö. L. (2010). Varyans analizi (anova - manova). İçinde Ş. Kalaycı (Edt.), Spss uygulamal çok değişkenli istatistik. teknikleri (ss. 131-82). Ankara: Asil Yayın Dağıtım.

Alican, C. ve Saban, A. (2013). Ortaokul ve lisede öğrenim gören öğrencilerin sosyal medya kullanımına ilişkin tutumları: Ürgüp örneği. Erciyes Üniversitesi Sosyal Bilimler Enstitiisü Dergisi, 35, 1-14.

Ayaydın, Y. ve Yıldız Ayaydın, H. (2018). Sosyal medyanın değer oluşturma sürecindeki rolünün öğrenci görüşleriyle incelenmesi. Değerler Eğitimi Dergisi, 16 (35), 57-89.

Bademci, V. (2006). Tartışmayı sonlandırmak: cronbach'ın alfa katsayısı, iki değerli $(0,1)$ ölçümlenmiş maddeler ile kullanılabilir. Kažm Karabekir Eğitim Fakültesi Dergisi, 13, 438-446.

Baştürk Akca, E., Sayımer, İ. ve Ergül, S. (2015). Ortaokul öğrencilerinin sosyal medya kullanımları ve siber zorbalık deneyimleri: Ankara örneği. Global Media Journal TR Edition, 5 (10), 71-86.

Baz, F. Ç. (2018). Sosyal medya bağımlllığı: Üniversite öğrencileri üzerine çalışma. OPUS-Uluslararası Toplum Arasttrmalar Dergisi, 9 (16), 276-295. DOI: 10.26466/opus.470118

Büyüköztürk, Ş., Kılıç Çakmak, E., Akgün, Ö. E., Karadeniz, Ş. ve Demirel, F. (2019). Eğitimde bilimsel araştrma yöntemleri. Pegem Akademi: Ankara.

Canbulat, M., Güven, Ö. ve Çağlar, M. Ç. (2017). Öğrenim düzeylerine göre gençlik dili değişkesi. International Journal of Language Acedemy, 5 (8), 111-126.

Çakır, İ. (2010). Yazma becerisinin kazanılması yabancı dil öğretiminde neden zordur?. Erciyes Üniversitesi Sosyal Bilimler Enstitïsü Dergisi, 28 (1), 165-176.

De Jonge, S. ve Kemp, N. (2012). Text-message abbreviations and language skills in high school and university students. Journal of Research in Reading, 35(1), 49-68.

Demir, Ü. (2016). Sosyal medya kullanımı ve aile iletişimi: Çanakkale'de lise öğrencileri üzerine bir araştırma. Selģu Iletisim, 9 (2), 27-50.

Deniz, L. ve Gürültü, E. (2018). Lise öğrencilerinin sosyal medya bağımllılkları. Kastamonu Education Journal, 26 (2), 355-367. doi:10.24106/kefdergi.389780

Derwing, T. M. ve Waugh, E. (2012). Language skills and the social integration of Canada's adult immigrants. IRPP Study, 31, 1-32.

Eriksson, M., Marschik, P. B., Tulviste, T., Almgren, M., Pérez Pereira, M., Wehberg, S., ... Gallego, C. (2012). Differences between girls and boys in emerging language skills: evidence from 10 language communities. British Journal of Developmental Psychology, 30, 326-343.

Fidan, M. (2019). Ortaokul öğrencilerinin Türkçe dersinde kullandıkları eleştirel dinleme stratejilerinin çeşitli değişkenler yönünden incelenmesi. RumeliDE Dil ve Edebiyat Araşturmalarn Dergisi, (15), 79-98. DOI: 10.29000/rumelide. 580463

Geers, A. E., Nicholas, J. G. ve Sedey, A. L. (2003). Language skills of children with early cochlear implantation. Ear and Hearing, 24, 46-58.

Görü Doğan, T. (2015). Sosyal medyanın öğrenme süreçlerinde kullanımı: ters-yüz edilmiş ögrenme yaklaşımına ilişkin öğrenen görüşleri, Açıkögretim Uygulamalar ve Araştrmalar Dergisi, 1(2), 24-48.

Güneş, F. (2011). Dil öğretim yaklaşımları ve Türkçe öğretimindeki uygulamalar. Mustafa Kemal Üniversitesi Sosyal Bilimler Enstitiisï Dergisi, 8(15), 123 - 148.

Güneș, F. (2012). Bologna süreci ile yükseköğretimde öngörülen beceri ve yetkinlikler. Yüksekë̈̆gretim ve Bilim Dergisi, $2(1), 1-9$.

Güneş, F. (2013). Yapılandırıc yaklaşımla dil bilgisi öğretimi. Eğitimde Kuram ve Uygulama, 9(3), 171-187.

Jones, S. M., Bouffard, S. M. ve Weissbourd, R. (2013). Educators' social and emotional skills vital to learning. Phi Delta Kappan, 94(8), 62-65.

Kalayc1, Ş. (2010). Faktör analizi. İçinde Ş. Kalaycı (Edt.), Spss uygulamal çok değişkenli istatistik teknikleri (ss. 321-331). Ankara: Asil Yayın Dağıtım.

Kamiloğlu, F. ve Yurttaş, Ö. U. (2014). Sosyal medyanın bilgi edinme ve kişisel gelişim sürecine katkısı ve lise öğrencileri üzerine bir alan çalışması. İleti-s-sim, 21, 129-150.

Karasar, N. (2009). Bilimsel araşttrma yöntemleri. Ankara: Nobel Yayın Dağııım.

Karatay, H. (2007). Dil edinimi ve değer öğretimi sürecinde masalın önemi ve işlevi. Türk Eğitim Bilimleri Dergisi, 5(3), $463-475$. 
Kayış, A. (2010). Güvenilirlik analizi. İçinde Ş. Kalayc1 (Edt.), Spss uygulamah çok değişkenli istatistik teknikleri (ss. 403419). Ankara: Asil Yayın Dağıtım.

Kula Kartal, S. ve Mor Dirlik, E. (2016). Geçerlik kavramının tarihsel gelişimi ve güvenirlikte en çok tercih edilen yöntem: cronbach alfa katsayıs1. Abant İzzet Baysal Üniversitesi Ĕ̈itim Fakültesi Dergisi, 16(4), 1865-1879.

Küçükali, A. (2016). Üniversite öğrencilerinin sosyal medya kullanımı: Atatürk Üniversitesi örneği. Bartın Üniversitesi İ.̇.B.F. Dergisi, 7(13), 531-546.

MEB (2019). Türkçe dersi öğretim programı. Erişim adresi: http://mufredat.meb.gov.tr/Dosyalar/20195716392253$02-\mathrm{T} \% \mathrm{C} 3 \% \mathrm{BCrk} \% \mathrm{C} 3 \% \mathrm{~A} 7 \mathrm{e} \% 20 \% \mathrm{C} 3 \% 96 \% \mathrm{C} 4 \% 9$ Fretim $\% 20$ Program $\% \mathrm{C} 4 \% \mathrm{~B} 1 \% 202019$.pdf

Nation, K. ve Snowling, M. J. (2004). Beyond phonological skills: broader language skills contribute to the development of reading. Journal of Research in Reading, 27(4), 342-356.

Nation, K., Cocksey, J., Taylor, J. S. H., Bishop, D. V. M. (2010). A longitudinal investigation of early reading and language skills in children with poor reading comprehension. Journal of Child Psychology and Psychiatry, 51(9), 1031-1039.

Nelson, K. E., Welsh, J. A., Trup, E. M. V. ve Greenberg, M. T. (2011). Language delays of impoverished preschool children in relation to early academic and emotion recognition skills. First Language, 31(2), 164-194.

Özdemir, Z. (2015). Sosyal medyada kimlik inşasında yeni akım: özçekim kullanımı. Maltepe Üniversitesi İletişim Fakültesi Dergisi, 2(1), 112-131.

Puolakanaho, A., Ahonen, T., Aro, M., Eklund, K., Leppanen, P. H., Poikkeus, A. M., Tolvanen, A., Torppa, M. ve Lyytinen, H. (2007). Very early phonological and language skills: estimating individual risk of reading disability. Journal of Child Psychology and Psychiatry, 48(9), 923-931.

Sarsar, F., Başbay, M. ve Başbay, A. (2015). Öğrenme-öğretme sürecinde sosyal medya kullanımı. Mersin Üniversitesi Ë̈itim Fakültesi Dergisi, 11(2), 418-431.

Sigman, M. ve McGovern, C. W. (2005). Improvement in cognitive and language skills from preschool to adolescence in autism. Journal of Autism and Developmental Disorders, 35(1), 15-23.

Temizyürek, F. (2007). İlköğretim ikinci kademede konuşma becerisinin geliştirilmesi. Ankara Üniversitesi Eğitim Bilimleri Fakültesi Dergisi, 40(2), 113-131.

Toğay, A., Akdur, T. E., Yetişken, İ. C. ve Bilici, A. (2013). Eğitim süreçlerinde sosyal ağların kullanımı: Bir MYO deneyimi. XIV. Akademik Bilisim Konferansı, 28-30 Ocak, Antalya.

Tutgun Ünal, A. (2015). Sosyal medya băğmhlĭğ: üniversite ögrencileri üzerine bir araştırma (Doktora tezi). Marmara Üniversitesi Sosyal Bilimler Enstitüsü, İstanbul.

Vural, Z. B. A. ve Bat, M. (2010). Yeni bir iletişim ortamı olarak sosyal medya: Ege Üniversitesi iletişim fakültesine yönelik bir araştırma. Journal of Yaşar University, 20(5), 3348 - 3382.

Yaylak, E. ve İnan, S. (2018). Sosyal bilgiler öğretmenlerinin eğitimde sosyal medyanın kullanılmasına yönelik görüşlerinin incelenmesi. TÜBAD, 3 (1), 1-32.

\section{EXTENDED ABSTRACT}

The use of language skills has an important role in establishing individual and social communication. Along with social adaptation, skills such as entrepreneurship and effective rhetoric can be described as reflections of individuals' language skills. This important situation has caused researchers to focus especially on the development of language skills. It is seen that most of the studies conducted in this field are about minimizing the problems experienced by students regarding language skills. The existence of aspects of social media applications such as mass communication and information sharing raises the issue of how they affect the development of student's communication skills and academic skills.

The widespread use of social media applications by individuals necessitates the determination of the effects of such applications on education and training processes. Tutgun Ünal $(2015, \mathrm{p} .182)$ found that there is a high rate of social media addiction among students in his research on the use of social media by university students. She also states that social media addiction causes various communication problems between individuals (Tutgun Ünal, 2015, s. 184). Accordingly, our study aimed to evaluate the effect of social media applications on students' academic and communication skills in line with the students' views. It is thought that taking students' opinions in this direction will contribute positively to reaching the data examined in the research.

The screening model was used in this study, which aims to determine the effects of social media applications on students' academic and communication skills through students' opinions. It is possible to list the basic research items of this study as follows:

1. Do social media applications affect the academic skills of the students according to the opinions of vocational and technical Anatolian high school students?

2. Do social media applications affect the communication skills of students according to the opinions of vocational and technical Anatolian high school students? 
3. In what ways do social media applications affect academic and communication skills (if they affect) according to the opinions of vocational and technical Anatolian high school students?

The sample of this research is Vocational and Technical Anatolian High School, students. A purposeful sampling method was used in the study. The samples of the research consisted of students from a Vocational and Technical Anatolian High School in Istanbul. The reason why Vocational and Technical Anatolian High School students were chosen as the sampling group of the study is that their education is in the fields of technology. This research was implemented in the 2020-2021 academic year. The research was applied to students who came to the school where the research was conducted during the periods of face-to-face education. The principle of voluntarism was sought in participating in the research process. A total of 92 students from the informatics, electrical electronics, and construction technologies departments participated in the study.

In this study, a survey was used in the process of collecting data. In the process of preparing the statements in the attitude survey used in the study, the scope of the study was primarily taken into consideration. In this context, items were tried to be prepared for the effects of social media applications on students' communicative and academic skills in the creation of statements.

In this study, quantitative research methods were used to evaluate the data. Accordingly, the data obtained in the Likert-type attitude survey, which was prepared to determine the effect of social media applications on students' academic and communication skills, was analyzed. The variables that are taken into consideration in the study are class level and gender. During the evaluation of the data, T-test, Anova (Variance analysis), frequency (f), and percentage rate (\%) calculations were made. Spss 20 program was used to make these calculations.

According to the results of this study, it was observed that students generally used social media applications. According to the results of the research, it is seen that the answers given by the students in the fields of language skills are generally positive.

In addition, it was determined that most of the students thought that using these applications did not affect their communication with their friends negatively, and in addition, using these applications had a positive effect on recognition by teachers.

It was observed that the majority of the students participating in the study stated that they could access universal information through social media applications and share this information with their environment.

It has been determined that the majority of the students participating in the research believe that such applications will have a positive effect on academic development when used only for educational purposes. Otherwise, it was determined that they thought they did not contribute positively to their lessons. 


\section{Ek - Tutum ölçeğinde bulunan ifadeler}

1. Sosyal medya uygulamalarını genelde kullanırım.

2. Sosyal medya uygulamalarını kullanmak özgüvenimi olumlu yönde geliştirir.

3. Sosyal medya uygulamalarının kullanımında ebeveyn, öğretmen vb. denetimi gereklidir.

4. Sosyal medya uygulamalarını kullanmak değerler sistemimi olumlu etkiler.

5. Sosyal medyada tanınırlığı yüksek olanların özgüvenleri de yüksektir.

6. Sosyal medyada tanınırlık öğrenci için sosyal bir statü ifade etmez.

7. Sosyal medya uygulamalarını kullanmak öğrencinin ailesi ile iletişimini olumlu etkiler.

8. Sosyal medya uygulamalarını kullanmak öğrencinin çevresi ile iletişimini olumsuz etkiler.

9. Sosyal medya uygulamalarını kullanmamak öğrencinin arkadaşları ile iletişimini olumsuz etkiler.

10. Sosyal medya uygulamalarını kullanan öğrenciler, kullanmayan öğrencilere göre öğretmenleri tarafindan daha çok tanınırlar.

11. Sosyal medya uygulamalarını kullanmanın dil becerilerimin gelişimini olumlu yönde etkilediğini düşünüyorum.

12. Sosyal medya uygulamalarını kullanmanın dinlediğimi ve izlediğimi anlama becerilerimi olumlu yönde geliştirdiğini düşünüyorum.

13. Sosyal medya uygulamalarını kullanmanın okuduğumu anlama becerilerimi olumlu yönde geliştirdiğini düşünüyorum.

14. Sosyal medya uygulamalarını kullanmanın kendimi yazılı olarak ifade etme becerilerimi olumlu yönde geliştirdiğini düşünüyorum.

15. Sosyal medya uygulamalarını kullanmanın kendimi sözlü olarak ifade etme becerilerimi olumlu yönde geliştirdiğini düşünüyorum.

16. Sosyal medya uygulamalarını kullanmanın derslerimde bana olumlu yönde katkısı yoktur.

17. Sosyal medya uygulamalarını denetimli kullanmak öğrencinin akademik gelişimine olumlu yönde etki yapar.

18. Sosyal medya uygulamalarını kullanmak öğrencinin öğretmenleri ile iletişimini olumlu etkiler.

19. Sosyal medya uygulamalarını eğitim amaçlı kullanmak öğrencinin akademik gelişimine olumlu yönde etki yapar.

20. Sosyal medya uygulamalarını kullanmanın kültürel bilgi birikimimi olumlu yönde geliştirdiğini düşünüyorum.

21. Sosyal medya uygulamalarını kullanarak evrensel düzeyde bilgiye erişebiliyorum.

22. Sosyal medya uygulamalarını kullanmanın yaratıcı düşünme becerilerime olumlu yönde etkisinin olduğunu düşünmüyorum.

23. Sosyal medya uygulamalarını kullanmanın eleştirel düşünme becerilerime olumlu yönde etkisinin olduğunu düşünmüyorum.

24. Sosyal medya uygulamalarını kullanmanın araştırma becerilerime olumlu yönde etkisinin olduğunu düşünmüyorum.

25. Bu uygulamalar vasıtası ile elde edilen bilgiler genelde güvenilirdir.

26. Bu uygulamalardan edindiğim bilgileri ders sürecinde sınıftaki arkadaşlarımla, öğretmenimle paylaşırım.

27. Öğrencilerin bu tür uygulamaları kullanmaları sırasında ailelerin, kurumların vb. denetim yapması gerektiğini düşünüyorum.

28. Öğrencilerin bu tür uygulamaları daha verimli kullanabilmeleri için öğretmenlerin, uzmanların vb. bilgilendirme ve rehberlik yapmaları gerektiğini düşünüyorum. 